Article

\title{
Synthesis of FAU-Type Zeolite Membranes with Antimicrobial Activity
}

\author{
T. Jean Daou 1,2,*(D), Thomas Dos Santos ${ }^{1,2}$, Habiba Nouali ${ }^{1,2}$, Ludovic Josien ${ }^{1,2}$, \\ Laure Michelin ${ }^{1,2}$, Laurent Pieuchot ${ }^{1,2}$ and Patrick Dutournie 1,2 \\ 1 Institut de Science des Matériaux de Mulhouse (IS2M), Université de Haute Alsace (UHA), CNRS, \\ UMR 7361, 3 bis rue Alfred Werner, F-68093 Mulhouse, France; thomas.dos-santos@uha.fr (T.D.S.); \\ habiba.nouali@uha.fr (H.N.); ludovic.josien@uha.fr (L.J.); laure.michelin@uha.fr (L.M.); \\ laurent.pieuchot@uha.fr (L.P.); patrick.dutournie@uha.fr (P.D.) \\ 2 Université de Strasbourg (UniStra), F-67000 Strasbourg, France \\ * Correspondence: jean.daou@uha.fr; Tel.: +33-389336739
}

Received: 10 July 2020; Accepted: 24 July 2020; Published: 28 July 2020

\begin{abstract}
In this study, a layer of a pure and dense phase of FAU-type zeolite was synthesized directly on the surface of $\alpha-\mathrm{Al}_{2} \mathrm{O}_{3}$ plane macroporous support. Before hydrothermal synthesis, a step of cleaning of the support by an anionic detergent was performed, a roughness surface is created, allowing the anchoring of the zeolite nuclei and then their growth, favoring in this sense the formation of a homogeneous zeolite layer. The obtained membranes were fully characterized using X-ray diffraction analysis (XRD), nitrogen sorption, scanning electron microscopy (SEM), and mercury porosimetry. After $24 \mathrm{~h}$ of thermal treatment at $75^{\circ} \mathrm{C}$, a homogeneous zeolite layer composed of bipyramidal crystals of FAU-type zeolite is obtained with a thickness of about $2.5 \mu \mathrm{m}$. No obvious defects or cracks can be observed. It was found that the increase in heating temperature could lead to the appearance of an impurity phase, GIS-type zeolite. Then the ideal zeolite membrane was exchanged with $\mathrm{Ag}^{+}$or $\mathrm{Zn}^{2+}$ cations to studies their antimicrobial properties. Zeolites membranes exchanged with $\mathrm{Ag}^{+}$showed an agar-diffusive bactericidal activity against gram negative Escherichia coli (E. coli) bacteria. $\mathrm{Zn}^{2+}$ exchanged zeolite membrane presented a bacteriostatic activity that is less diffusive in agar. As expected, non-exchanged zeolite membrane (in its $\mathrm{Na}^{+}$form) have no effect on bacterial activity. This process is particularly interesting for the synthesis of a good quality FAU-type zeolite membranes with antimicrobial properties.
\end{abstract}

Keywords: FAU-type zeolite; membrane; zeolites; in-situ synthesis; ionic exchange; bactericidal activity

\section{Introduction}

Zeolites are a microporous crystalline aluminosilicate with a three-dimensional network composed of $\mathrm{SiO}_{4}$ and $\mathrm{AlO}_{4}$ tetrahedrally interconnected by oxygen bridges [1,2]. Due to their excellent textural properties and high thermal (up to $700{ }^{\circ} \mathrm{C}$ ) and chemical stabilities, zeolite materials offer unique frames for a wide variety of industrial applications (catalysis, molecular decontamination, separation, adsorption, energy storage, etc.). The substitution of Si atoms by $\mathrm{Al}$ atoms in the zeolite framework creates negative charge that should be compensated by cations (the most common compensating cations are $\mathrm{Na}^{+}$). These cations can be easily exchanged by silver, copper, or zinc cations to confer to zeolites antibacterial, antiviral, and antifungal activities [3-9]. Silver-exchanged zeolites have antibacterial and antifungal properties against a broad spectrum of microscopic bacteria and fungi (Escherichia Coli, Pseudomonas aeruginosa, Bacilus cereus, Staphylococcus aureus, Candida albicans, Candida glabata, Aspergillus niger and Penicillium vinaceum, etc.). They can be considered as a credible alternative to 
materials functionalized with silver nanoparticles, because their activity is similar or even higher. Generally, the antibacterial activity depends on the silver content, but certain zeolites exchanged with silver show a significant efficiency in the elimination of bacteria, despite their very low silver content $(<0.2 \%)$ [5]. In the case of zeolites, not only the silver content, but other parameters (structural type, crystal size, and $\mathrm{Si} / \mathrm{Al}$ ratio of the framework) can influence the activity [3-9].

Zeolites exchanged with silver face a great problem which is their high cost. It is known that other transition metals such as copper, zinc, etc. can show antibacterial properties at a much lower cost [9]. Thus, zeolites exchanged by these metal cations have been prepared and tested for their antibacterial properties. Milenkovic et al. [9], studied the antibacterial activity of zeolites exchanged with copper and zinc towards E. coli and compared with that of zeolites exchanged with silver. A natural clinoptilolite zeolite (NZ) and a zeolite A (LTA, Linde 4A) were exchanged with transition metal ions. All materials showed a similar content of transition metals $-0.24-0.28 \mathrm{mmol} / \mathrm{g}$ of zeolite. The exchange of copper and zinc has been shown to lead to a sharp increase in antibacterial activity compared to non-exchanged zeolites with the exception of the Zn-NZ zeolite. However, the effectiveness of these materials remains lower than that of zeolites exchanged with silver. Antibacterial activity decreases as follows: $\mathrm{Ag}-\mathrm{NZ} \approx \mathrm{Ag}-\mathrm{A}>\mathrm{Cu}-\mathrm{NZ} \approx \mathrm{Cu}-\mathrm{A}>\mathrm{Zn}-\mathrm{NZ}>>\mathrm{Zn}-\mathrm{A}$. The release of zinc and copper ions into the solution was considerably less than that of silver, suggesting that the mechanism of antibacterial activity in exchanged zeolites is directly related to the materials and not to the released ions. In general, the bacteria removal efficiency of the zeolite varies depending on the nature of the metal cation used in the following order: $\mathrm{Ag}^{+}>\mathrm{Cu}^{2+}>\mathrm{Fe}^{3+}>\mathrm{Zn}^{2+}>\mathrm{Ni}^{2+}$.

Unfortunately, conventional syntheses of zeolites give often rise to powders composed of micron-size crystals. These powders cannot be used directly for industrial applications, especially for water purification and molecular sieving [10]. A shaping step has to occur before using them. Zeolite membranes are potentially used in industry for molecular separation, water treatment, electrical sensors and insulation because of their high thermal stability and uniform pore size [10-15]. Various types of zeolitic membranes, especially MFI [16,17], SOD [18], LTA [10,18] and FAU [19,20], have been reported for molecules or gaseous separation and/or adsorption. In particular, FAU-type zeolite membranes are suitable for the separation of large molecules due to their 12-membered oxygen rings pore openings with a diameter of $0.74 \mathrm{~nm}$ [21]. These zeolite membranes can be synthesized by direct in situ crystallization or by seeding and secondary growth process [22-27]. However, it appears that the direct in situ synthesis of FAU-type zeolite membranes without defect remains a challenge because of the low heterogeneous nucleation of the zeolite on the used support. Mainly intended to cover the surface of the support with a layer of zeolite seeds before the growth step, the secondary growth process leads to the formation of a uniform and dense layer on the surface of the support. Compared with in-situ hydrothermal growth method, the secondary growth method has more advantages for manipulating the microstructure of the membrane, in particular for adjusting the thickness and orientation of the crystals, since the nucleation process can be separated from crystalline growth [23].

To date, various techniques have been developed to improve the direct in-situ crystallization of homogeneous FAU-type zeolite membrane on macroporous alumina support. Huang, et al. [28,29] and Zhou, et al. [30] used 3-aminopropyltriethoxysilane (APTES) as covalent linker between the FAU-type zeolite layer and the porous alumina support. The 3-aminopropylsilane moieties have been used as highly effective molecular binders to promote the binding and anchoring of zeolite nuclei to the macroporous alumina surface during hydrothermal synthesis. Zhou, et al. [31] used polydopamine (PDA) to prepare dense pure phase FAU-type zeolite membranes on the surface of PDA-modified $\alpha-\mathrm{Al}_{2} \mathrm{O}_{3}$ macroporous tubes. It was found that PDA facilitated the growth of the FAU-type zeolite layer on the $\alpha-\mathrm{Al}_{2} \mathrm{O}_{3}$ tubes and reduced the synthesis time to obtain a high quality FAU-type zeolite membrane.

In this project, a strategy was developed to synthesize highly crystallized FAU-type zeolite membranes by in situ crystallization and in the absence of organic structuring. The zeolite layer was generated directly on the surface of the macroporous $\alpha-\mathrm{Al}_{2} \mathrm{O}_{3}$ plates treated with Alconox ${ }^{\circledR}$ an anionic 
detergent, without the use of any other binder or tie layer. The ideal FAU-type zeolite membranes were then exchanged with silver and zinc cations to confer them antibacterial properties.

\section{Results and Discussion}

\subsection{Hydrothermal Synthesis of FAU-Type Zeolite Membranes}

The treated supports were immersed in the synthesis solution as described in Section 3.3 and subjected to hydrothermal treatment. The influence of the synthesis time on the growth of the film has been studied. The synthesis time varied from 12 to $24 \mathrm{~h}$. Zeolitic membrane growth and their crystallization state were investigated using X-ray diffraction (XRD) technique, which shows characteristic patterns of pure FAU-type zeolite in agreement with the corresponding pattern available (Pattern 01-070-4281 from International Center of Diffraction Data (ICDD)) [32-34] (Figure 1) with additional peaks at high $2 \theta$ angles attributed to $\alpha-\mathrm{Al}_{2} \mathrm{O}_{3}$ composing the support [24,35]. The crystallinity of the synthesized FAU-type zeolite membranes increases progressively with the crystallization time as shown by the increase of the intensity of the XRD diffraction peaks in Figure 1. XRD patterns were indexed in the cubic symmetry (space group $\mathrm{Fd}-3 \mathrm{~m}$ ) and lattice parameters $\left(\mathrm{a}_{0}\right)$ were determined with STOE Win X Pow software [36]. From these parameters, the Si/Al framework ratios were deduced using Breck and Flanigen's equation:

$$
\left(\mathrm{Si} / \mathrm{Al}=\left((192 \times 0.00868) /\left(\mathrm{a}_{0}-24.191\right)\right)-1\right),
$$

with $\mathrm{a}_{0}$ cell parameter [32,37]. A silicon to aluminum molar ratio around 1.2 is obtained for the synthesized FAU-type zeolite membranes. This $\mathrm{Si} / \mathrm{Al}$ ratio of 1.2 is attributed to zeolite $\mathrm{X}$ of FAU-type [21,32].

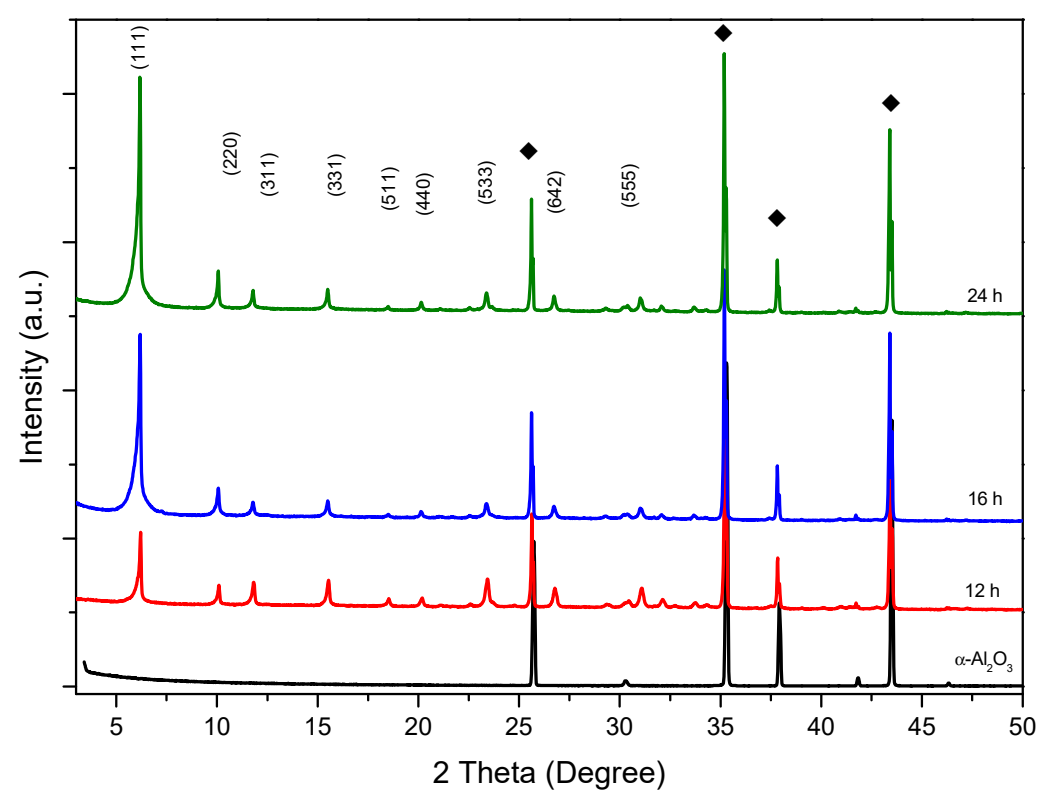

Figure 1. X-ray diffraction (XRD) patterns of FAU-type zeolite membranes prepared on Alconox ${ }^{\circledR}$-treated $\alpha-\mathrm{Al}_{2} \mathrm{O}_{3}$ supports at $75{ }^{\circ} \mathrm{C}$ for 12,16 , and $24 \mathrm{~h}$. (Black diamonds indicate the peaks of $\alpha-\mathrm{Al}_{2} \mathrm{O}_{3}$ support).

Scanning electron microscopy (SEM) investigations were performed on the obtained FAU-type zeolite membranes (Figure 2). As shown in Figure 2a, after $12 \mathrm{~h}$ of synthesis, crystals are observed and a thin layer of a thickness of about 1 micron covers the entire surface of the support. After $16 \mathrm{~h}$ of treatment (Figure 2b) the bipyramidal morphology of FAU-type zeolite crystals was observed confirming the increase of crystallinity as observed above from XRD patterns. At this point, a continuous layer of 
FAU-type zeolite with a thickness of about $1.7 \mu \mathrm{m}$ is formed on the surface of the support. The crystals continue to grow until reaching their final bypyramidal morphology after $24 \mathrm{~h}$ of thermal treatment. As shown in Figure 2c, after 24 h of synthesis, the FAU-type zeolite crystals are well crystallized (in correlation with XRD results) and a layer of FAU-type zeolite of $2.5 \mu \mathrm{m}$ in thickness is obtained. Thus, under these ideal conditions of in situ hydrothermal synthesis in one step, a dense, crack-free, FAU-type zeolite membrane is formed on the treated $\alpha-\mathrm{Al}_{2} \mathrm{O}_{3}$ macroporous support.

(a)
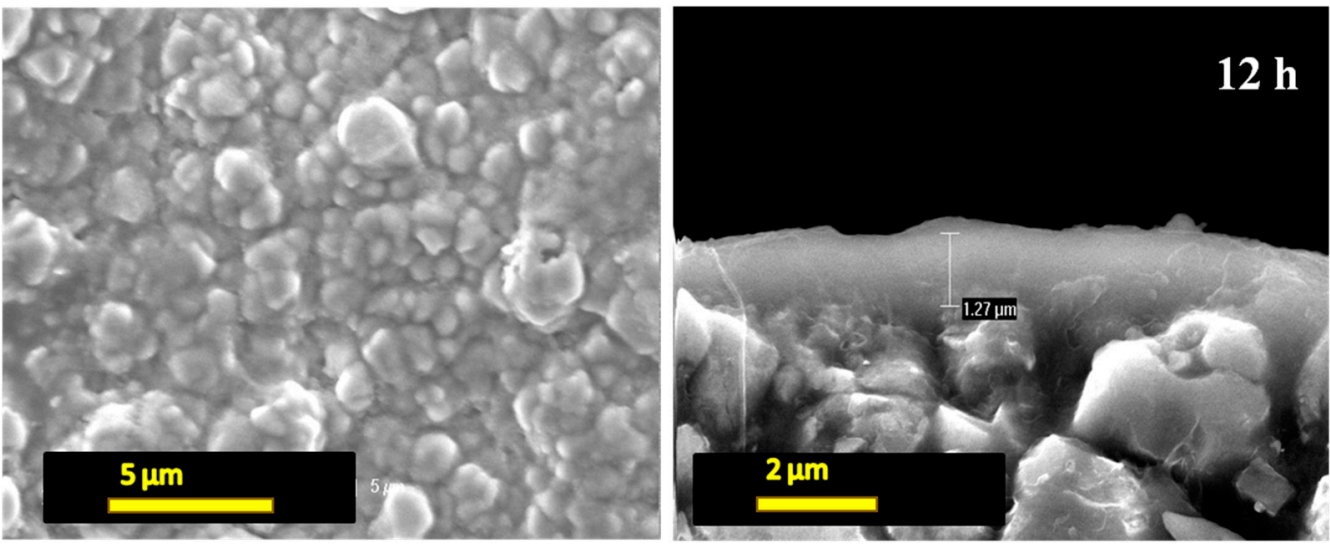

(b)
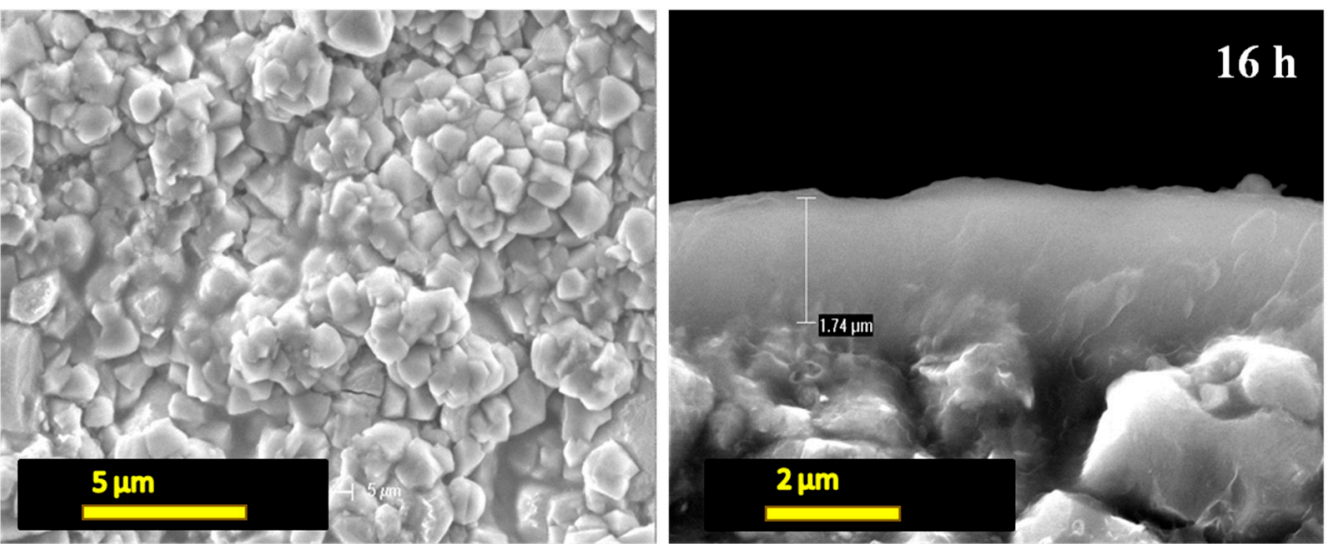

(c)
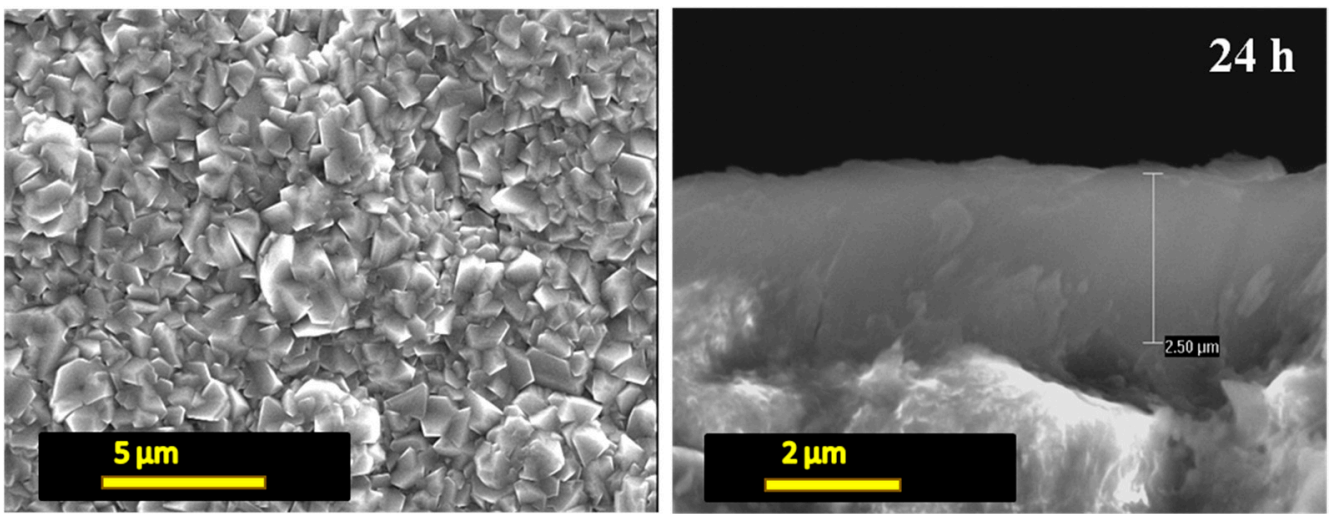

Figure 2. Cont. 
(d)

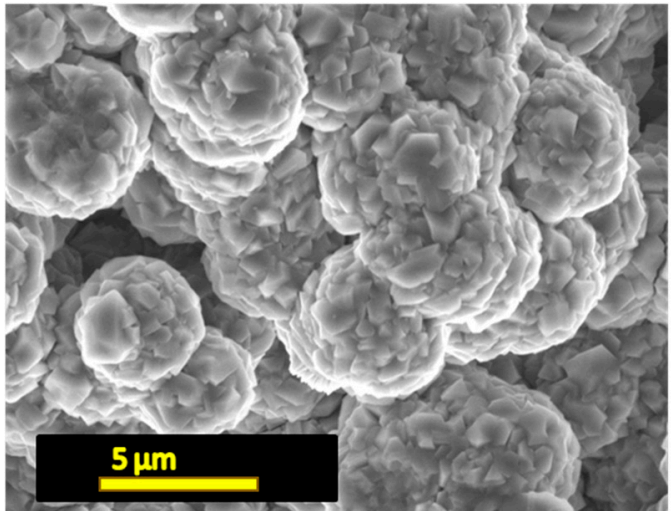

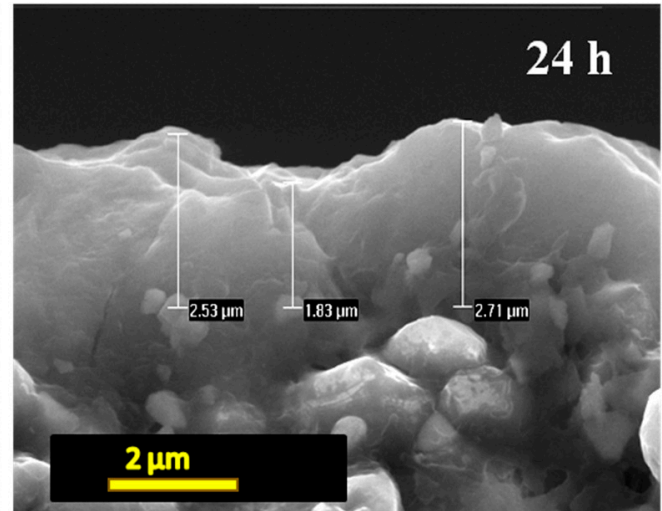

Figure 2. Scanning electron microscopy (SEM) images of FAU-type zeolite membranes prepared on Alconox ${ }^{\circledR}$-treated $(\mathbf{a}-\mathbf{c}) \alpha-\mathrm{Al}_{2} \mathrm{O}_{3}$ support at $75{ }^{\circ} \mathrm{C}$ for 12,16 and $24 \mathrm{~h}$. SEM images of FAU-type zeolite membranes prepared on untreated (d) $\alpha-\mathrm{Al}_{2} \mathrm{O}_{3}$ support at $75{ }^{\circ} \mathrm{C}$ for $24 \mathrm{~h}$. Top view (left); cross-section of the surface (right).

In order to show the importance of the Alconox ${ }^{\circledR}$ treatment step, the same synthesis was done at $75^{\circ} \mathrm{C}$ for $24 \mathrm{~h}$ using this time an untreated $\alpha-\mathrm{Al}_{2} \mathrm{O}_{3}$ macroporous support. As it is shown in Figure $2 \mathrm{~d}$ a set of non-homogeneous aggregates of FAU-type zeolite crystals are formed on the surface of the $\alpha-\mathrm{Al}_{2} \mathrm{O}_{3}$ support instead of a homogeneous FAU-type zeolite film once treated $\alpha-\mathrm{Al}_{2} \mathrm{O}_{3}$ macroporous support is used. This result confirms the importance of Alconox ${ }^{\circledR}$ treatment step on the formation of homogenous zeolite layer as already observed in our previous paper [24,35,38-40].

The nitrogen sorption properties of the best FAU membrane obtained after Alconox ${ }^{\circledR}$ treatment of the substrate and a thermal treatment at $75{ }^{\circ} \mathrm{C}$ for $24 \mathrm{~h}$ were investigated to evaluate the micropores accessibility and to determine the amount of zeolite deposited on the surface of $\alpha-\mathrm{Al}_{2} \mathrm{O}_{3}$ support. Figure 3 reports the nitrogen adsorption isotherm of the obtained zeolite membrane. The textural properties are shown in Table 1. The adsorption isotherm is of type I at low relative pressure, according to the International Union of Pure and Applied Chemistry (IUPAC) classification [41,42] which is characteristic of microporous materials. It should be noted that the sample was degassed at $300{ }^{\circ} \mathrm{C}$ for $15 \mathrm{~h}$ under vacuum, without going through a calcination step due to the absence of organic template in the zeolite framework. This temperature was chosen to eliminate the physisorbed water and Volatile Organic Compounds (VOC) molecules. According to the nitrogen adsorption isotherm, the zeolite layer formed has a total adsorbed volume of $1.04 \mathrm{~cm}^{3} / \mathrm{g}$ at Standard conditions of Temperature and Pressure (STP) at relative pressure of 0.1 , including the mass of the support (which does not adsorb nitrogen), the microporous volume of zeolite layer could be deduced: $1.6 \times 10^{-3} \mathrm{~cm}^{3} / \mathrm{g}$ (see Table 1).

Table 1. The results of $\mathrm{N}_{2}$ physisorption of the zeolite layers obtained on treated macroporous $\alpha-\mathrm{Al}_{2} \mathrm{O}_{3}$ supports, after $24 \mathrm{~h}$ of synthesis at the heating temperature at $75{ }^{\circ} \mathrm{C}$.

\begin{tabular}{cccc}
\hline Zeolite-Type & $\begin{array}{c}\text { Adsorbed Volume } \\
\left(\mathrm{cm}^{\mathbf{3}} / \mathrm{g}_{\text {sample }} \text { STP) }\right.\end{array}$ & $\begin{array}{c}\mathrm{V}_{\text {micro }}{ }^{\mathbf{b}} \text { Zeolite Layer } \\
\left(\mathrm{cm}^{\mathbf{3}} / \mathrm{g}_{\text {sample }}\right)\end{array}$ & $\begin{array}{c}\text { Zeolite Weight on Support } \\
(\mathbf{m g})\end{array}$ \\
\hline FAU & 1.04 & $1.6 \times 10^{-3}$ & $\sim 22.9$ \\
\hline
\end{tabular}

${ }^{a}$ Deduced from $\mathrm{N}_{2}$ adsorption isotherm at relative pressure of $0.1 .{ }^{\mathrm{b}}$ Microporous volume of the zeolite layer determined; value determined by the t-plot method. ${ }^{c}$ Determined from Equation (2). 


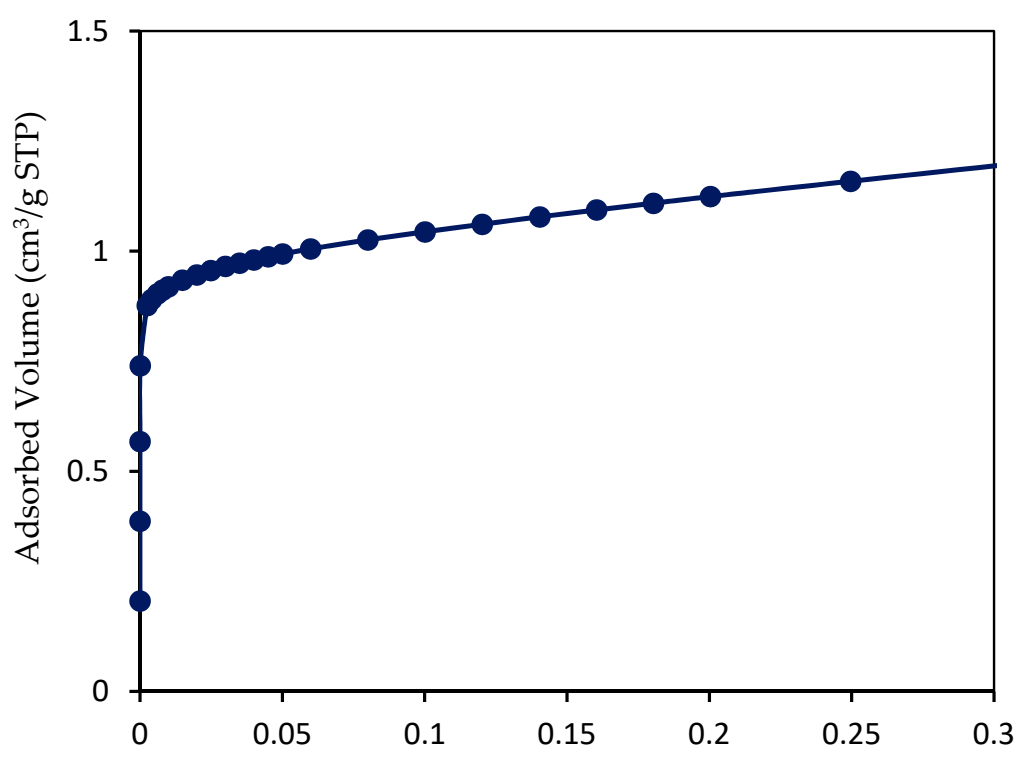

Relative Pressure $\left(\mathrm{p} / \mathrm{p}^{\circ}\right)$

Figure 3. Nitrogen adsorption isotherm at $-196^{\circ} \mathrm{C}$ of the FAU-type membrane after $24 \mathrm{~h}$ of thermal treatment. The adsorbed volume is expressed in $\mathrm{cm}^{3}$ per gram of the total sample, including the mass of the alumina support.

Knowing this value and comparing it with that obtained for the equivalent powder from the same composition of FAU-type zeolite synthesis $\left(207 \mathrm{~cm}^{3} / \mathrm{g} \mathrm{STP}\right)$, makes it possible to determine the mass of zeolite deposited on the support. Equation 2 is based on the assumption that all the porosity of the zeolite layer is accessible [38-40,43]. It is possible to calculate the mass of the zeolite layer [38-40,43]. The mass of the sample $\left(\mathrm{m}_{\text {total }}\right.$ (sample)), including the support and the zeolite layer, is determined by weighing $\left(\mathrm{m}_{\text {total }}=4.57 \mathrm{~g}\right)$ after degassing. On the basis of this equation, the $\alpha-\mathrm{Al}_{2} \mathrm{O}_{3}$ support could be coated with $22.9 \mathrm{mg}$ of FAU-type zeolite, $\left[\left(1.04 \mathrm{~cm}^{3} / \mathrm{g} \times 4.57 \mathrm{~g}\right) / 207 \mathrm{~cm}^{3} / \mathrm{g}\right]$. This result is in agreement with the mass composition determined by weighing. In consequence, the whole porosity of the microporous film is accessible.

$$
m(\text { layer })=\frac{V(\text { sample }) \times m_{\text {total }}(\text { sample })}{V(\text { equivalent powder })}
$$

The mercury intrusion experiment carried out on the best FAU-type membrane (and the uncoated alumina substrate as reference) confirmed the formation of a continuous zeolite film on the surface of the alumina macroporous support (Figure 4). A reduction by approximately $8 \%$ of the mean macropore diameter from $967 \mathrm{~nm}$ (uncoated alumina substrate) to $886 \mathrm{~nm}$ (alumina substrate coated with zeolite layer) is observed on the pore size distributions shown in Figure 4. Macropores, therefore remain accessible.

\subsection{Ion-Exchange}

FAU-type zeolite membrane $2 \times 2 \mathrm{~cm}^{2}$ obtained after Alconox ${ }^{\circledR}$ treatment and a thermal treatment at $75^{\circ} \mathrm{C}$ for $24 \mathrm{~h}$ were cut into different small membranes then ion exchange was done and repeated on three different small membranes for each cation. Scanning electron microscopy and Energy Dispersive X-ray (EDX) mapping of the FAU-type membrane obtained after ionic exchange with silver or zinc salts are shown in Figure 5. Inspection of these results reveals that the replacement of $\mathrm{Na}^{+}$compensating cations (present in the microporosity of the zeolite to counter balance the negative charge generated by the presence of aluminum in the zeolite framework) by $\mathrm{Ag}+$ and $\mathrm{Zn}^{2+}$ does not affect the morphology 
of FAU-type zeolites. For the silver-treated membranes and zinc-treated membranes a homogeneous distribution of silver and zinc is observed in Figure 5c,f. The EDX mapping of silicon in Figure 5b,e shows the presence at the surface of the exchanged membranes of a homogeneous layer of Si elements confirming that zeolites are still present at the surface. This result was then confirmed by XRD patterns shown in Figure 6 which show that all the identified peaks on exchanged zeolite membranes are attributed to FAU-type zeolite (Pattern 01-079-1884 for Ag exchanged FAU-type zeolite and pattern 04-009-7258 for $\mathrm{Zn}$ exchanged FAU-type zeolite, ICDD) and $\alpha-\mathrm{Al}_{2} \mathrm{O}_{3}$. Changes in peaks intensities and slight shifts are observed when sodium cations are replaced by other silver or zinc cations. These results were already observed in the literature [33,44-48] and were explained as a consequence of the difference of the scattering power which is specific to each cation and also by a slightly different sites occupation in the pores $[33,48,49]$.

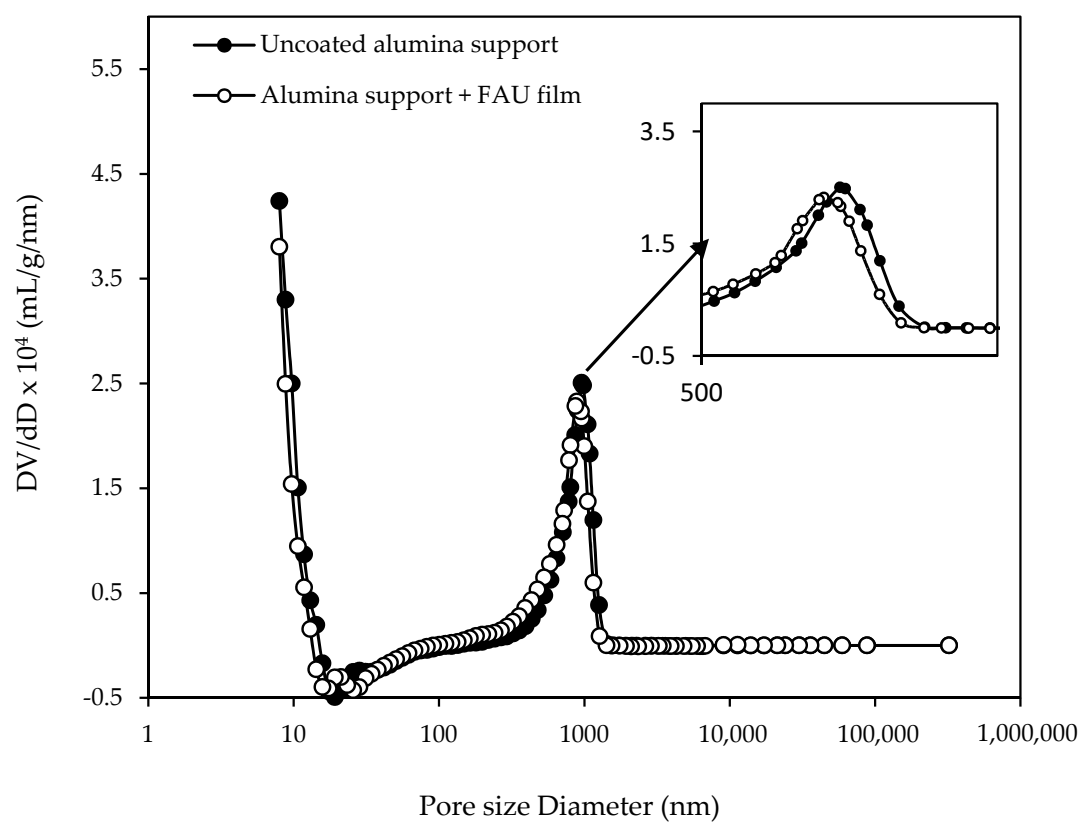

Figure 4. Pore size distribution of the uncoated alumina support (solid symbol) and the coated alumina support with FAU-type zeolite layer after $24 \mathrm{~h}$ of thermal treatment (empty symbol) performed by mercury porosimetry with a zoom on the region with pore size diameter between 500 and $1100 \mathrm{~nm}$.
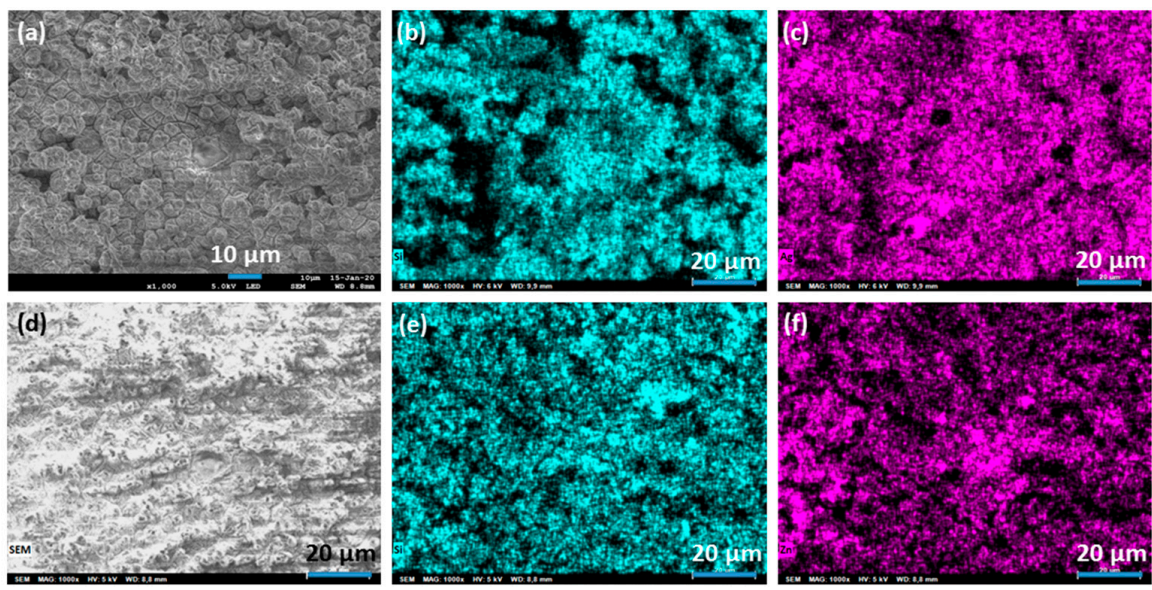

Figure 5. SEM images of FAU-zeolite membranes exchanged with silver (a) or zinc (d) and Energy Dispersive X-ray (EDX) mapping of silicon $(\mathbf{b}, \mathbf{e})$, silver $(\mathbf{c})$ and zinc (f) elements present in these FAU-zeolite membranes. 


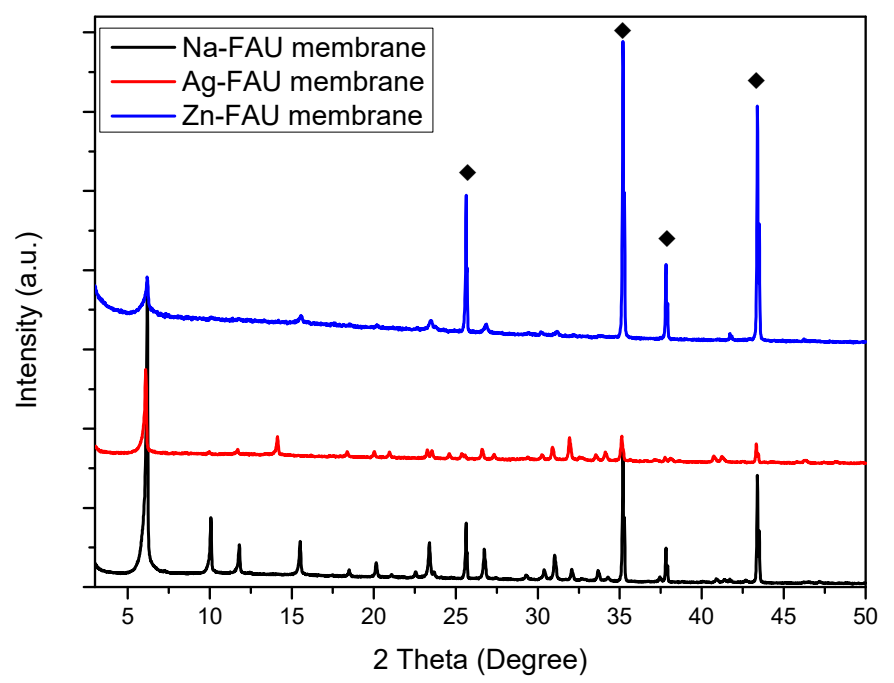

Figure 6. XRD patterns of Na-FAU membrane on $\alpha-\mathrm{Al}_{2} \mathrm{O}_{3}$ supports, silver exchanged FAU membrane and zinc exchanged FAU membrane. Black diamonds indicate the peaks of $\alpha-\mathrm{Al}_{2} \mathrm{O}_{3}$ support.

\subsection{Antibacterial Activity of the Zeolitic Membrane}

The antibacterial activity of the zeolite samples was tested against gram-negative Escherichia coli (E. coli) bacteria via the agar diffusion method, colony-forming unit counting and live/dead staining analyzed by confocal microscopy.

\subsubsection{Inhibition through Diffusion}

We used an agarose diffusion assay to assess the ability of the zeolite complexes to inhibit the growth of bacteria through diffusion. The results show that zeolite membrane exchanged with $\mathrm{Ag}^{+}$ was capable of inhibiting the growth of E. coli bacteria. Distance of the inhibition zones and standard deviations are shown in Figure 7a. The largest inhibition zones were observed for $\mathrm{Ag}^{+}$exchanged zeolite $(1.6 \mathrm{~mm})$. There was no inhibition halo around the other zeolite membranes.

\subsubsection{Impact on the Colony Forming Activity of a Bacterial Suspension}

The impact of the zeolite complexes on the colony forming activity of a bacterial suspension (Figure $7 \mathrm{~b}$ ) was assessed. Support without zeolite coating was used as a negative control. Un-exchanged zeolite (sodium form) shows no antibacterial activity, exhibiting the same Colony Forming Units (CFUs) as the control. No CFUs were observed from the solution incubated with the $\mathrm{Ag}^{+}$zeolite membrane, meaning that all bacteria were killed during the incubation. This demonstrates the strong bactericidal properties of the zeolitic membrane doped with $\mathrm{Ag}^{+}$. A significant decrease in colony forming activity was observed for the bacterial solutions incubated with $\mathrm{Zn}^{2+}$ exchanged zeolite membrane, suggesting a significant antimicrobial activity for this membrane.

\subsubsection{Live and Dead Bacteria Quantification on the Zeolite Surfaces}

The viability of bacteria on the zeolite surfaces by fluorescence microscopy was monitored using a syto9/propidium iodide staining method. Cells with a compromised membrane that are considered dead or dying exhibited a red fluorescence whereas cells with an intact membrane will stained green (Figure 7c). On $\mathrm{Ag}^{+}$exchanged membrane surface, almost all bacteria were found dead, comforting our previous results. Interestingly, $\mathrm{Zn}^{2+}$ exchanged zeolite membrane showed less bacteria than the un-exchanged zeolite membrane $\left(\mathrm{Na}^{+}\right.$form) surface, but most cells were alive, suggesting bacteriostatic rather than bactericidal properties (Figure $7 \mathrm{~d}, \mathrm{e}$ ). 
(a)

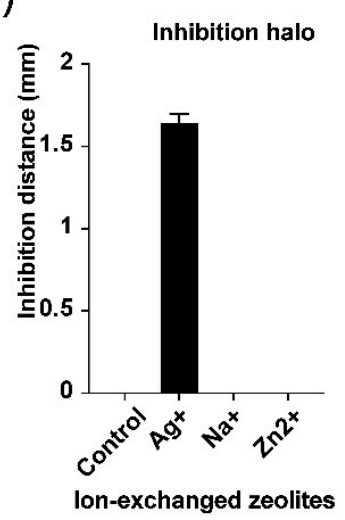

(b)

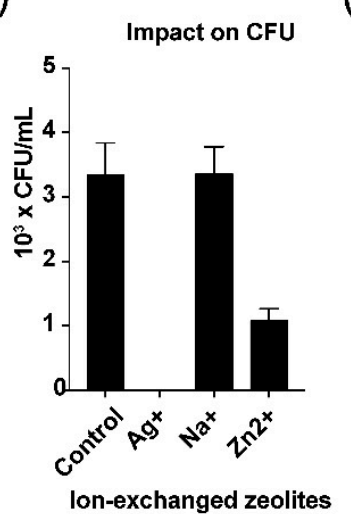

(c)

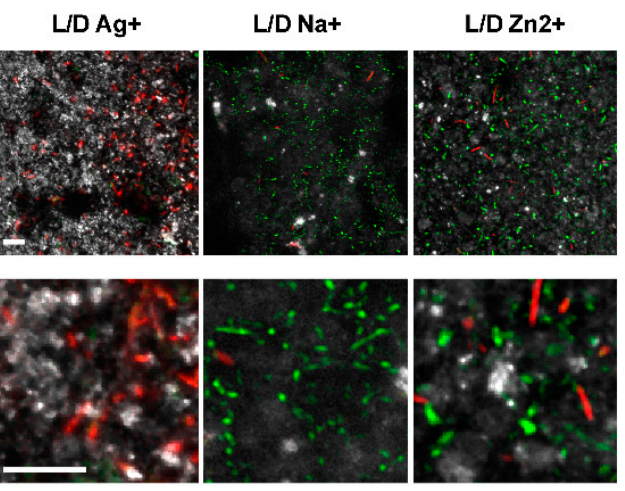

(d)

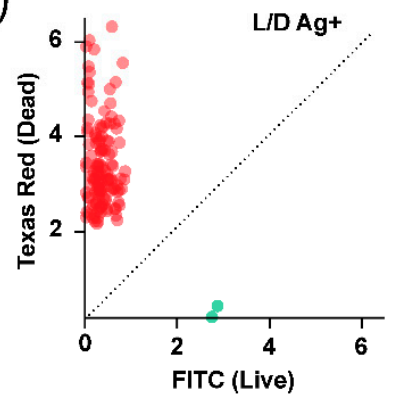

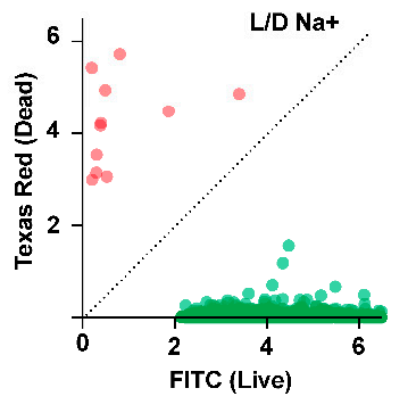

L/D Zn2+

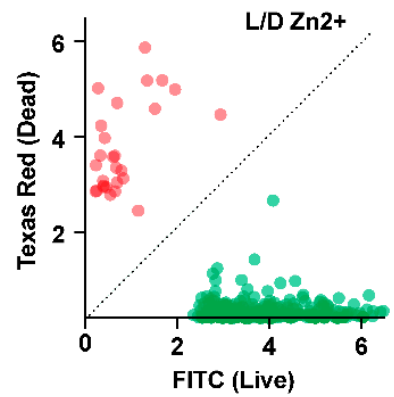

(e)

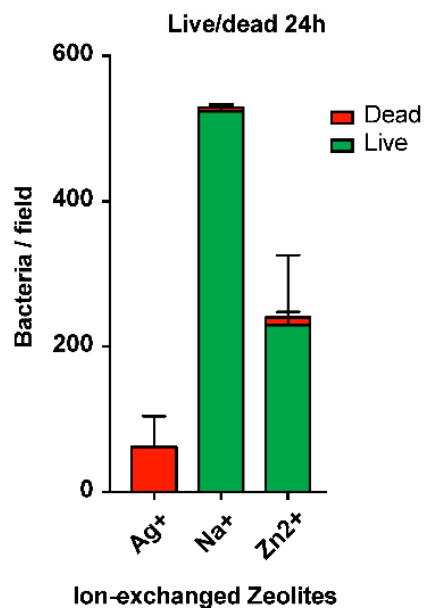

Figure 7. Antimicrobial activity of ion-exchanged zeolites. (a) Inhibition distances of $E$. coli bacteria growth by Na-FAU zeolite membrane and ion-exchanged $\left(\mathrm{Ag}^{+}\right.$and $\left.\mathrm{Zn}^{2+}\right)$ zeolite membranes measured by agarose diffusion assay. (b) Antibacterial activity of the zeolites measured by CFU counts on agar plates. (c) Fluorescence microscope images of E. coli cells on the surface of ion-exchanged zeolites after live/dead staining (syto9 in green, propidium iodide in red, scale presented on the image correspond to $10 \mu \mathrm{m}$ ). The surface is observed using laser reflection (gray levels). (d) Quantification of the overall live populations (green) compared to dead populations (red). (e) Integration of the data presented in (d) showing the live/dead ratio and the total amount of bacteria on the zeolite surfaces.

\section{Materials and Methods}

\subsection{Materials and Reagents}

All chemicals were used as received without further purification: LUDOX AS-40 colloidal silica (40 wt.\% in water) was used as Si source, whereas Sodium Aluminate ( $\left(50-56\right.$ wt.\% $\mathrm{Al}_{2} \mathrm{O}_{3}, 40-45$ wt.\% $\mathrm{Na}_{2} \mathrm{O}$,) was used as the $\mathrm{Al}$ source zeolite synthesis. Anionic detergent (Alconox ${ }^{\circledR}$ ) was used to increase the anchoring of zeolite particles on macroporous $\alpha-\mathrm{Al}_{2} \mathrm{O}_{3}$ support. Silver nitrate $\left.(\mathrm{AgNO})_{3}\right)$ was used as $\mathrm{Ag}^{+}$source for cation exchange process. All of these reagents were purchased from Sigma-Aldrich (Saint Louis, $\mathrm{MO}, \mathrm{USA})$. Zinc chloride $\left(\mathrm{ZnCl}_{2}, \geq 98 \mathrm{wt}\right.$ \%) was purchased from Fluka (Illkirch, France) and used as $\mathrm{Zn}^{2+}$ source for cation exchange process. Other chemicals used in this work are sodium 
hydroxide (NaOH, >99.9 wt.\%, Carlo Erba (Val-de-Reuil, France)), and deionized water ( 18 m $2 . \mathrm{cm})$. Macroporous $\alpha-\mathrm{Al}_{2} \mathrm{O}_{3}$ plates $8 \times 8 \mathrm{~cm}^{2}$ (2 mm thick, $1 \mu \mathrm{m}$ pore size, $99 \%$ porosity) were purchased from FINAL Advanced Materials (Didenheim, France) and cut to $2 \times 2 \mathrm{~cm}^{2}$ plates. The chemical composition of macroporous $\alpha-\mathrm{Al}_{2} \mathrm{O}_{3}$ support was determined by PANalytical X-ray Fluorescence spectrometer (XRF) (PANalytical, Limeil-Brévannes, France) which is listed in Table 2.

Table 2. Chemical Composition of macroporous $\alpha-\mathrm{Al}_{2} \mathrm{O}_{3}$ plate.

\begin{tabular}{cc}
\hline Chemical Component & Mass Fraction (\%) \\
\hline $\mathrm{Al}_{2} \mathrm{O}_{3}$ & 98.63 \\
$\mathrm{ZrO}_{2}$ & 0.64 \\
$\mathrm{SiO}_{2}$ & 0.30 \\
$\mathrm{CaO}$ & 0.12 \\
$\mathrm{Fe}_{2} \mathrm{O}_{3}$ & 0.09 \\
$\mathrm{~K}_{2} \mathrm{O}$ & 0.06 \\
$\mathrm{Na}_{2} \mathrm{O}$ & 0.05 \\
Others & $<0.01$ \\
\hline
\end{tabular}

\subsection{Pretreatment of the Support}

Firstly, the anionic detergent (Alconox ${ }^{\circledR}, 3 \mathrm{~g}$ ) was dissolved in $400 \mathrm{~mL}$ of deionized water heated to $60{ }^{\circ} \mathrm{C}$ according to the procedure reported elsewhere [38-40]. Subsequently, the surfaces of the macroporous $\alpha-\mathrm{Al}_{2} \mathrm{O}_{3}$ support were cleaned in this Alconox ${ }^{\circledR}$ aqueous solution for $1 \mathrm{~h}$. This step aims to create a higher number of anchoring points for zeolite nuclei on the surface of the alumina during the synthesis step. Finally the plates were removed from the solution, rinsed with distilled water and dried at $70{ }^{\circ} \mathrm{C}$ before being cooled down to ambient temperature.

\subsection{Hydrothermal Synthesis of FAU-Type Zeolite Membranes}

In order to prepare the FAU-type membranes, a clear synthesis solution with the molar ratio of $70 \mathrm{Na}_{2} \mathrm{O}: 1 \mathrm{Al}_{2} \mathrm{O}_{3}: 20 \mathrm{SiO}_{2}: 2000 \mathrm{H}_{2} \mathrm{O}$ [50] was obtained by mixing aluminate solution (S1) and silicate solution (S2) at $70{ }^{\circ} \mathrm{C}$ according to an adapted procedure from previous paper [51]. In the first step, sodium hydroxide was dissolved in deionized water at room temperature, then sodium aluminate was added to obtain the solution (S1). Solution (S2) was prepared by mixing LUDOX AS-40 colloidal silica and deionized water at $70{ }^{\circ} \mathrm{C}$. The solution (S2) was added into the solution (S1) under vigorous stirring. After few minutes, a clear, homogeneous solution was obtained. The resulting mixture was stirred overnight at room temperature. The treated or non-treated $\alpha-\mathrm{Al}_{2} \mathrm{O}_{3}$ supports were horizontally placed in a Teflon-lined stainless steel autoclave, and then the synthesis solution was poured into the autoclave and heated for 4 to $24 \mathrm{~h}$ at $75^{\circ} \mathrm{C}$. After the hydrothermal growth, the prepared zeolite FAU membrane were rinsed with deionized water and placed in an ultrasonic bath for 5 min to remove the loosely attached crystals and finally dried at $110^{\circ} \mathrm{C}$ overnight.

\subsection{Ion-Exchange}

FAU-type zeolite membranes obtained at $75^{\circ} \mathrm{C}$ after $24 \mathrm{~h}$ of thermal treatment were modified by exchanging the sodium compensating cations present in the parent zeolites with silver $\left(\mathrm{Ag}^{+}\right)$ or zinc $\left(\mathrm{Zn}^{2+}\right)$ cations by a cationic exchange process using silver nitrate $\left(\mathrm{AgNO}_{3}\right)$ or zinc chloride $\left(\mathrm{ZnCl}_{2}\right)$ aqueous solutions $(1 \mathrm{M})$. Typically, FAU-type zeolite membrane was blended with the $1 \mathrm{M}$ cationic aqueous solution that was prepared by mixing $\mathrm{AgNO}_{3}$ salt (2.6 g) or $\mathrm{ZnCl}_{2}$ salt (2.73 g) with $20 \mathrm{~mL}$ of demineralized water. The reaction mixture was then heated at $80{ }^{\circ} \mathrm{C}$ for $2 \mathrm{~h}$ under stirring. The mass ratio of the reaction mixture is $1 \mathrm{~g}$ of zeolite for $20 \mathrm{~mL}$ for electrolyte aqueous solution. The $\mathrm{pH}$ value of the mixtures was between 6 and 7. After completion of the ion exchange reaction between the $\mathrm{Ag}^{+}, \mathrm{Zn}^{2+}$ and $\mathrm{Na}^{+}$, the zeolites membranes were washed 3 times under stirring with cold demineralized water $(\sim 200 \mathrm{~mL})$. As silver cation is sensitive to lights and heats, the Ag exchanged 
FAU membranes were dried in the dark at $80{ }^{\circ} \mathrm{C}$ under nitrogen. After each cationic exchange the samples were characterized.

\subsection{Agarose Diffusion Assay}

E. coli strain was grown overnight $(\mathrm{ON})$ in Luria Bertani $(\mathrm{LB})$ broth in an incubator shaker at $37^{\circ} \mathrm{C}(200 \mathrm{rpm})$. Then, the culture was diluted at $10^{8}$ bacteria/mL and $100 \mu \mathrm{L}$ were spread evenly onto LB agar Petri dishes. Lids were left open for $5 \mathrm{~min}$ in a laminar flow cabinet to allow for any excess surface moisture to be absorbed into the agar. Zeolite membranes were applied to the surfaces and the plates were inverted and incubated at $37^{\circ} \mathrm{C} \mathrm{ON}$ to allow for bacterial growth.

\subsection{Colony Forming Unit Assay}

E. coli strain was pre-grown ON in LB broth at $37^{\circ} \mathrm{C}(200 \mathrm{rpm})$. The bacterial culture was diluted to 0.1 optical density units (OD, measured at $\lambda=600 \mathrm{~nm}$ ) and incubate at $37^{\circ} \mathrm{C}$ (incubator shaker, $200 \mathrm{rpm}$ ) until it reached $0.6 \mathrm{OD}$. Zeolite samples were inoculated with $3 \mathrm{~mL}$ of a $1 / 100$ dilution of the bacterial solution in $35 \mathrm{~mm}$ Petri dishes and incubated ON. We performed serial dilutions from the resulting culture and plated $10 \mu \mathrm{L}$ onto LB agar plates in triplicate. The plates were then incubated at $37^{\circ} \mathrm{C}$ for $24 \mathrm{~h}$ and CFUs were counted.

\subsection{Live/Dead Assay}

An ON bacterial culture was diluted to $0.1 \mathrm{OD}$ and incubate at $37^{\circ} \mathrm{C}$ until it reached $0.6 \mathrm{OD}$. Zeolite samples were inoculated with $3 \mathrm{~mL}$ of a 1/100 dilution of the bacterial solution in $35 \mathrm{~mm}$ Petri dishes and incubated ON. We used the LIVE/DEAD BacLight ${ }^{\mathrm{TM}}$ Bacterial Viability Kit (Thermofisher, Waltham, MA, USA) to quantity the number and the viability of bacteria on the zeolite surfaces. Briefly, zeolite samples were stained with a PBS solution (phosphate buffered saline, $\mathrm{pH}$ 7.4) containing SYTO9 and propidium iodide fluorophores for $15 \mathrm{~min}$ followed by a $5 \mathrm{~min}$ wash step in PBS alone. A confocal laser scanning microscope (LSM800, Zen software, Zeiss, Marly le roi, France) was used to visualize the stained bacteria. Image analysis was done using ImageJ. Graphs were generated using Prism 7 (GraphPad software, San Diego, CA, USA).

\subsection{Characterization}

X-ray diffraction (XRD) patterns were collected on a PANalytical X'PertPro diffractometer (Limeil-Brévannes, France) using CuK $\alpha$ radiation $(\lambda=1.5418 \AA$ ) and $\theta-\theta$ mounting at room temperature under ambient pressure. The patterns were registered in $2 \theta$ range from $5^{\circ}$ to $50^{\circ}$ with a scanning step of $0.013^{\circ} 2 \theta$ and a time per step of $200 \mathrm{~s}$. The $\mathrm{Si} / \mathrm{Al}$ molar ratio was determined from the refinement of the unit cell parameters of the non-calcined films. From these parameters, the Si/Al framework ratios of the zeolite layer were deduced using the Breck and Flanigen [37]. The morphology, homogeneity and thickness of different zeolite films were determined with Scanning Electron Microscopy (SEM) using a Philips XL-30 FEG microscope (FEI-Thermo Fisher Scientific, Eindhoven, Netherlands). Energy dispersive X-ray (EDX) analyses were a JEOL JSM-7900F microscope (Croissy sur Seine, France) equipped with BRUKER QUANTAX EDX spectrometer (Synergie4, Evry, France). In order to investigate the cations distribution in our materials, element maps were collected at $6 \mathrm{kV}$ (for $\mathrm{AgX}$ zeolites) or $5 \mathrm{kV}$ (for $\mathrm{ZnX}$ zeolites) accelerating voltage.

The porosities of the uncoated and coated alumina plate were analyzed by mercury intrusion porosimetry using an Autopore IV porosimeter (Micromeritics, Merignac, France). This device allows working at pressures between $2.6 \times 10^{-6}$ and $400 \mathrm{MPa}$. Before the measurements, the alumina plates were degassed at $300{ }^{\circ} \mathrm{C}$ under vacuum (100 Pa) for approximately $12 \mathrm{~h}$. About $300-800 \mathrm{mg}$ of degassed alumina plate (coated or not) were introduced into the penetrometer, which was then placed in the low-pressure chamber $\left(2.6 \times 10^{-6}-0.2 \mathrm{MPa}\right)$. During this first step, the cell was evacuated and filled with mercury. The penetrometer containing broken pieces of uncoated or coated alumina plates and mercury was then placed in the high pressure chamber (0.2-400 MPa). During this second step, 
pressure was applied to force the diffusion of mercury into the porous sample. As the intrusion occurs, the level of mercury in the stem varies. The Washburn equation [51] was used to process the data: $\mathrm{P} \times \mathrm{D}=4 \sigma \cos \theta$, where $\mathrm{P}$ is the applied pressure $(\mathrm{Pa}), \mathrm{D}$ is the pore diameter $(\mathrm{m}), \sigma$ is the interfacial tension $\left(\mathrm{N} \cdot \mathrm{m}^{-1}\right)$, and $\theta$ the contact angle $\left(^{\circ}\right)$ (for mercury $\sigma=485 \mathrm{mN} \cdot \mathrm{m}^{-1}$ and $\theta=130^{\circ}$ ). Nitrogen adsorption-desorption isotherms were performed at $-196{ }^{\circ} \mathrm{C}$ using ASAP 2420 apparatus (Micromeritics, Merignac, France). Prior to each manometric experiment, the zeolitic samples were outgassed under vacuum for $1 \mathrm{~h}$ at $90^{\circ} \mathrm{C}$ then $15 \mathrm{~h}$ at $300^{\circ} \mathrm{C}$ to eliminate physisorbed water and VOC molecules. The microporous volume $\left(\mathrm{V}_{\text {micro }}\right)$ was calculated by $\mathrm{t}$-plot method.

\section{Conclusions}

In this work, a FAU-type zeolite layer was synthesized on macroporous alumina plates. After gentle cleaning to make the plate surfaces rougher, a $24 \mathrm{~h}$ in situ hydrothermal treatment proved to be the optimal condition for obtaining a very good quality membrane. A dense and continuous layer of FAU-type zeolite with a thickness of $2.5 \mu \mathrm{m}$ was formed directly on the surface of the alumina support, without any crack. An Si/Al molar ratio of 1.2 and the crystal morphology of the FAU-type zeolite were determined. The accessibility of the porosity of the formed film was verified by $\mathrm{N}_{2}$ physisorption analysis. A simple and fast method has therefore been developed to synthesize very good quality FAU-type zeolite membranes. Zeolites membranes exchanged with $\mathrm{Ag}^{+}$showed an agar-diffusive bactericidal activity against gram negative E. coli bacteria. $\mathrm{Zn}^{2+}$ exchanged zeolites presented a bacteriostatic activity that is less diffusive in agar. As expected, non-exchanged zeolite membrane (in its $\mathrm{Na}^{+}$form) have no effect on bacterial activity.

Author Contributions: Conceptualization, T.J.D. and P.D.; methodology, T.J.D. and L.P.; formal analysis, T.D.S., H.N., L.J., and L.M.; investigation, T.D.S. and L.P.; writing-original draft preparation, T.J.D; writing-review and editing, T.J.D.; project administration, T.J.D.; funding acquisition, T.J.D. All authors have read and agreed to the published version of the manuscript.

Funding: Funding for T.J.D. was received from the Institut Universitaire de France (IUF).

Acknowledgments: The authors would like to thanks the IS2M characterization platforms for their help in the characterization of the samples. Funding from the Institut Universitaire de France (IUF) is gratefully acknowledged.

Conflicts of Interest: The authors declare no conflict of interest.

\section{References}

1. Striebel, C.H.; Hoffmann, K.; Marlow, F. The microcrystal prism method for refractive index measurements on zeolite-based nanocomposites. Microporous Mater. 1997, 9, 43-50. [CrossRef]

2. Ferch, H. Zeolites and clay minerals as sorbents and molecular sieves. Von, R.M. Barrer. Academic Press, London-New York 1978. 1. Aufl., VII, 497 S., zahlr. Abb. u. Tab., Ln. Chem. Ing. Tech. 1980, 52, 366. [CrossRef]

3. Jiraroj, D.; Tungasmita, S.; Tungasmita, D.N. Silver ions and silver nanoparticles in zeolite a composites for antibacterial activity. Powder Tech. 2014, 264, 418-422. [CrossRef]

4. Saint-Cricq, P.; Kamimura, Y.; Itabashi, K.; Sugawara-Narutaki, A.; Shimojima, A.; Okudo, T. Antibacterial activity of silver-loaded "green zeolites". Eur. J. Inorg. Chem. 2012, 21, 3398-3402. [CrossRef]

5. Lalueza, P.; Monzon, M.; Arruebo, M.; Santamaria, J. Antibacterial action of Ag-containing MFI zeolite at low Ag loadings. J. Chem. Com. 2011, 47, 680-682. [CrossRef]

6. Tosheva, L.; Belkhair, S.; Gackowski, M.; Malica, S.; Al-Shanti, N.; Verran, J. Rapid screening of the antimicrobial efficacy of Ag zeolites. J. Coll. Surf. B 2017, 157, 254-260. [CrossRef]

7. Jędrzejczyk, R.J.; Turnau, K.; Jodłowski, P.J.; Chlebda, D.K.; Łojewski, T.; Łojewska, J. Antimicrobial properties of silver cations substituted to faujasite mineral. Nanomaterials 2017, 7, 240. [CrossRef]

8. Bedi, R.S.; Cai, R.; O’Neill, C.; Beving, D.E.; Foster, S.; Guthrie, S.; Chen, W.; Yan, Y. Hydrophilic and antimicrobial Ag-exchanged zeolite a coatings: A year-longdurability study and preliminary evidence for their general microbiocidal efficacyto bacteria, fungus and yeast. Microporous Mesoporous Mater. 2012, 151, 352-357. [CrossRef] 
9. Milenkovic, J.; Hrenovic, J.; Matijasevic, D.; Niksic, M.; Rajic, N. Bactericidal Activity of Cu-, Zn-, and Ag-containing zeolites toward escherichia coli isolates. Environ. Sci. Pollut. Res. 2017, 24, 20273-20281. [CrossRef]

10. Cho, C.H.; Oh, K.Y.; Kim, S.K.; Yeo, J.G.; Sharma, P. Pervaporative seawater desalination using NaA zeolite membrane: Mechanisms of high water flux and high salt rejection. J. Membr. Sci. 2011, 371, $226-238$. [CrossRef]

11. Duke, M.C.; O’Brien-Abraham, J.; Milne, N.; Zhu, B.; Lin, J.Y.S.; Diniz da Costa, J.C. Seawater desalination performance of MFI type membranes made by secondary growth. Sep. Purif. Technol. 2009, 68, 343-350. [CrossRef]

12. Wang, W.; Zhou, M.; Mao, Q.; Yue, J.; Wang, X. Novel NaY zeolite-supported nanoscale zero-valent iron as an efficient heterogeneous Fenton catalyst. Catal. Commun. 2010, 11, 937-941. [CrossRef]

13. McLeary, E.E.; Jansen, J.C.; Kapteijn, F. Zeolite based films, membranes and membrane reactors: Progress and prospects. Microporous Mesoporous Mater. 2006, 90, 198-220. [CrossRef]

14. Wang, Z.; Wang, H.; Mitra, A.; Huang, L.; Yan, Y. 20-P-11 Pure-silica zeolite low-k dielectric thin films by spin-on process. In Studies in Surface Science and Catalysis; Elsevier: Montpellier, France, 2001; Volume 135, p. 292.

15. Caro, J.; Noack, M. Zeolite membranes-Recent developments and progress. Microporous Mesoporous Mater. 2008, 115, 215-233. [CrossRef]

16. Yu, L.; Korelskiy, D.; Grahn, M.; Hedlund, J. Very high flux MFI membranes for alcohol recovery via pervaporation at high temperature and pressure. Sep. Purif. Technol. 2015, 153, 138-145. [CrossRef]

17. Lai, Z.; Bonilla, G.; Diaz, I.; Nery, J.G.; Sujaoti, K.; Amat, M.A.; Kokkoli, E.; Terasaki, O.; Thompson, R.W.; Tsapatsis, M.; et al. Microstructural optimization of a zeolite membrane for organic vapor separation. Science 2003, 300, 456-460. [CrossRef]

18. Wang, N.; Liu, Y.; Huang, A.; Caro, J. Hydrophilic SOD and LTA membranes for membrane-supported methanol, dimethylether and dimethylcarbonate synthesis. Microporous Mesoporous Mater. 2015, 207, $33-38$. [CrossRef]

19. Covarrubias, C.; García, R.; Yánez, J.; Arriagada, R. Preparation of CPB-modified FAU zeolite for the removal of tannery wastewater contaminants. J. Porous Mater. 2008, 15, 491-498. [CrossRef]

20. Zhu, G.; Li, Y.; Chen, H.; Liu, J.; Yang, W. An in situ approach to synthesize pure phase FAU-type zeolite membranes: Effect of aging and formation mechanism. J. Mater. Sci. 2008, 43, 3279-3288. [CrossRef]

21. Dhainaut, J.; Daou, T.J.; Chappaz, A.; Bats, N.; Harbuzaru, B.; Lapisardi, G.; Chaumeil, H.; Defoin, A.; Rouleau, L.; Patarin, J. Synthesis of FAU and EMT-type zeolites using structure-directing agents specifically designed by molecular modelling. Microporous Mesoporous Mater. 2013, 174, 117-125. [CrossRef]

22. Gascon, J.; Kapteijn, F.; Zornoza, B.; Sebastián, V.; Casado, C.; Coronas, J. Practical Approach to Zeolitic Membranes and Coatings: State of the Art, Opportunities, Barriers, and Future Perspectives. Chem. Mater. 2012, 24, 2829-2844. [CrossRef]

23. Shan, L.; Shao, J.; Wang, Z.; Yan, Y. Preparation of zeolite MFI membranes on alumina hollow fibers with high flux for pervaporation. J. Membr. Sci. 2011, 378, 319-329. [CrossRef]

24. Said, A.; Nouali, H.; Limousy, L.; Dutournié, P.; Josien, L.; Toufaily, J.; Hamieh, T.; Daou, T.J. Synthesis of mono- and bi-layer zeolite films on alumina substrates. C. R. Chim. 2016, 19, 486-495. [CrossRef]

25. Nikolakis, V.; Xomeritakis, G.; Abibi, A.; Dickson, M.; Tsapatsis, M.; Vlachos, D.G. Growth of a faujasite-type zeolite membrane and its application in the separation of saturated/unsaturated hydrocarbon mixtures. J. Membr. Sci. 2001, 184, 209-219. [CrossRef]

26. Lassinantti, M.; Hedlund, J.; Sterte, J. Faujasite-type films synthesized by seeding. Microporous Mesoporous Mater. 2000, 38, 25-34. [CrossRef]

27. Kita, H.; Fuchida, K.; Horita, T.; Asamura, H.; Okamoto, K. Preparation of faujasite membranes and their permeation properties. Sep. Purif. Technol. 2001, 25, 261-268. [CrossRef]

28. Huang, A.; Wang, N.; Caro, J. Seeding-free synthesis of dense zeolite FAU membranes on 3-aminopropyltriethoxysilane-functionalized alumina supports. J. Membr. Sci. 2012, 389, 272-279. [CrossRef]

29. Huang, A.; Wang, N.; Caro, J. Stepwise synthesis of sandwich-structured composite zeolite membranes with enhanced separation selectivity. Chem. Commun. 2012, 48, 3542-3544. [CrossRef]

30. Zhou, C.; Zhou, J.; Huang, A. Seeding-free synthesis of zeolite FAU membrane for seawater desalination by pervaporation. Microporous Mesoporous Mater. 2016, 234, 377-383. [CrossRef] 
31. Zhou, C.; Yuan, C.; Zhu, Y.; Caro, J.; Huang, A. Facile synthesis of zeolite FAU molecular sieve membranes on bio-adhesive polydopamine modified $\mathrm{Al}_{2} \mathrm{O}_{3}$ tubes. J. Membr. Sci. 2015, 494, 174-181. [CrossRef]

32. Borel, M.; Dodin, M.; Daou, T.J.; Bats, N.; Harbuzaru, B.; Patarin, J. SDA-free hydrothermal synthesis of high-silica ultra-nanosized zeolite Y. Cryst. Growth Des. 2017, 17, 1173-1179. [CrossRef]

33. Tahraoui, Z.; Nouali, H.; Marichal, C.; Forler, P.; Klain, J.; Daou, T.J. Influence of the compensating cation nature on the water adsorption properties of zeolites. Molecules 2020, 25, 944. [CrossRef] [PubMed]

34. Borel, M.; Dodin, M.; Daou, T.J.; Bats, N.; Patarin, J. Formation domain of SDA-free Y faujasite small crystals. New J. Chem. 2017, 41, 13260-13267. [CrossRef]

35. Said, A.; Limousy, L.; Nouali, H.; Michelin, L.; Halawani, J.; Toufaily, J.; Hamieh, T.; Dutournié, P.; Daou, T.J. Synthesis of mono- and bi-layer MFI zeolite films on macroporous alumina tubular supports: Application to nanofiltration. J. Cryst. Growth 2015, 428, 71-79. [CrossRef]

36. Boultif, A.; Louër, D.J. Indexing of powder diffraction patterns for low-symmetry lattices by the successive dichotomy method. Appl. Crystallogr. 1991, 24, 987-993. [CrossRef]

37. Breck, D.W.; Flanigen, E.M. Molecular Sieves; Barrer, R.M., Ed.; The Society of Chemical Industry: London, UK, 1968; p. 47.

38. Lauridant, N.; Daou, T.J.; Arnold, G.; Soulard, M.; Nouali, H.; Patarin, J.; Faye, D. Key steps influencing the formation of ZSM-5 films on aluminum substrates. Microporous Mesoporous Mater. 2012, 152, 1-8. [CrossRef]

39. Lauridant, N.; Daou, T.J.; Arnold, G.; Nouali, H.; Patarin, J.; Faye, D. Zeolite hybrid films for space decontamination. Microporous Mesoporous Mater. 2013, 172, 36-43. [CrossRef]

40. Daou, T.J.; Lauridant, N.; Arnold, G.; Josien, L.; Faye, D.; Patarin, J. Synthesis of MFI/EMT zeolite bi-layer films for molecular decontamination. Chem. Eng. J. 2013, 234, 66-73. [CrossRef]

41. Thommes, M.; Kaneko, K.; Neimark, A.V.; Olivier, J.P.; Rodriguez-Reinoso, F.; Rouquerol, J.; Sing, K.S.W. Physisorption of gases, with special reference to the evaluation of surface area and pore size distribution (IUPAC Technical Report). Pure Appl. Chem. 2015, 87, 1051-1069. [CrossRef]

42. Sing, K.S.W. Reporting physisorption data for gas/solid systems with special reference to the determination of surface area and porosity (Recommendations 1984). Pure Appl. Chem. 1985, 57, 603-619. [CrossRef]

43. Mosca, A.; Öhrman, O.; Hedlund, J.; Perdana, I.; Creaser, D. $\mathrm{NO}_{2}$ and $\mathrm{N}_{2}$ sorption in MFI films with varying $\mathrm{Si} / \mathrm{Al}$ and Na/Al ratios. Microporous Mesoporous Mater. 2009, 120, 195-205. [CrossRef]

44. Song, H.; Jiang, B.-L.; Song, H.-L.; Jin, Z.-S.; Sun, X.-L. Preparation of AgY zeolite and study on its adsorption equilibrium and kinetics. Res. Chem. Intermed. 2015, 41, 3837-3854. [CrossRef]

45. Xu, K.; Yuan, C.; Caro, J.; Huang, A. Silver-exchanged zeolite LTA molecular sieving membranes with enhanced hydrogen selectivity. J. Membr. Sci. 2016, 511, 1-8. [CrossRef]

46. Henao-Sierra, W.; Romero-Sáez, M.; Gracia, F.; Cacua, K.; Buitrago-Sierra, R. Water vapor adsorption performance of Ag and Ni modified 5A zeolite. Microporous Mesoporous Mater. 2018, 265, 250-257. [CrossRef]

47. Golbad, S.; Khoshnoud, P.; Abu-Zahra, N. Synthesis of 4A Zeolite and Characterization of Calcium- and Silver-Exchanged Forms. J. Miner. Mater. Charact. Eng. 2017, 5, 237-251. [CrossRef]

48. Price, L.; Leung, K.M.; Sartbaeva, A. Local and Average Structural Changes in Zeolite A upon Ion Exchange. Magnetochemistry 2017, 3, 42. [CrossRef]

49. Chandwadkar, A.J.; Chandwadkar, J.G.; Kulkarni, S.B. The influence of the size and concentration of alkaline earth ions on the structural and sorption properties of faujasites. J. Colloid Interface Sci. 1984, 97, 435-445. [CrossRef]

50. Zhu, G.; Li, Y.; Zhou, H.; Liu, J.; Yang, W. FAU-type zeolite membranes synthesized by microwave assisted in situ crystallization. Mater. Lett. 2008, 62, 4357-4359. [CrossRef]

51. Washburn, E.W. The Dynamics of Capillary Flow. Phys. Rev. 1921, 17, 273-283. [CrossRef]

Sample Availability: Samples of the compounds are not available from the authors. 